\title{
An antithrombin-dependent sulfated polysaccharide isolated from the green alga Caulerpa cupressoides has in vivo anti- and prothrombotic effects
}

\author{
Um polissacarídeo sulfatado dependente de antitrombina isolado da alga verde Caulerpa cupressoides \\ possui efeitos anti- e pró-trombótico in vivo
}

\author{
José Ariévilo Gurgel Rodrigues ${ }^{I}$ Ismael Nilo Lino de Queiroz ${ }^{I I}$ Ana Luíza Gomes QuinderéII \\ Bruno Cunha Vairo ${ }^{\mathrm{III}}$ Paulo Antônio de Souza Mourão ${ }^{\mathrm{III}}$ Norma Maria Barros Benevides ${ }^{\mathrm{I}, \mathrm{II}^{*}}$
}

\begin{abstract}
Red algae sulfated polysaccharides (SPs) have been widely described as anticoagulant and antithrombotic agents; however no description of antithrombotic activity regarding green algae SPS has been reported. Caulerpa cupressoides (Chlorophyta) has three different SPs fractions $\left(\mathrm{SP}_{1}, \mathrm{SP}_{2}\right.$ and $\left.\mathrm{SP}_{3}\right)$. We investigated the effects of $\mathrm{SP}_{2}$ on thrombin activity by antithrombin and in an experimental model of venous thrombosis in rats. The inhibition of thrombin assay was evaluated using antithrombin (AT) in the presence of $\mathrm{SP}_{2}$ and the antithrombotic activity was investigated in rats with thromboplastin as the thrombogenic stimulus. The anticoagulant effects of $\mathrm{SP}_{2}$ are suggested be due to the potentiation of thrombin inhibition by antithrombin $\left(I C_{50} \sim\right.$ $10.0 \mu \mathrm{g} \mathrm{mL}^{-1}$ ) and this mechanism of interaction is different when compared to other studied Caulerpa polysaccharides. $\mathrm{SP}_{2}$ exhibited antithrombotic effects at doses of 1.0 and $2.0 \mathrm{mg}$ $\mathrm{kg}^{-1}$ body weight, but at higher doses (>2.0mg $\mathrm{kg}^{-1}$ body weight) this polysaccharide revert the antithrombotic property. No hemorrhagic effect $\left(2.0 \mathrm{mg} \mathrm{kg}^{-1}\right)$ was observed. As occurs with red algae SPs, these results indicate that green algae SPs are also capable of exhibiting different in vivo properties.
\end{abstract}

Key words: green alga, sulfated polymers, biological events, coagulation system, thrombosis.

\section{RESUMO}

Os polissacarídeos sulfatados (PSs) de algas vermelhas têm sido relatados mundialmente como agentes anticoagulantes e antitrombóticos. Entretanto, nenhuma descrição de atividade antitrombótica tem sido relacionada com os PSs de algas verdes. A cloroficea Caulerpa cupressoides possui três frações de PSs $\left(P_{1} ; P_{2}\right.$ e PS $\left.S_{3}\right)$. Dessa forma, objetivou-se investigar os efeitos da fração $\mathrm{PS}_{2}$ sobre a atividade da trombina por antitrombina e usando um modelo experimental de trombose venosa em ratos. $O$ ensaio de inibição da trombina foi avaliado usando a antitrombina (AT) na presença de $\mathrm{PS}_{2}$ e a atividade antitrombótica foi investigada em ratos, usando a tromboplastina como o estímulo trombogênico. Os efeitos anticoagulantes de $\mathrm{PS}_{2}$ devem-se provavelmente à sua potência de inibir a trombina mediada pela $\mathrm{AT}\left(\mathrm{IC} \mathrm{C}_{50} \sim 10,0 \mu \mathrm{g} \mathrm{mL}^{-1}\right)$ e esse mecanismo de interação é diferente, comparado ao de outros polissacarídeos de Caulerpa estudados. PS $\mathrm{S}_{2}$ exibiu efeitos antitrombóticos nas doses de 1,0 e 2,0 $\mathrm{mg} \mathrm{kg}^{-1}$ peso corpóreo, mas em doses mais elevadas (>2,0mg kg-1 peso corpóreo) esse polissacarídeo exibe efeitos pró-trombóticos. Também não foi observado nenhum efeito hemorrágico (2,0mg $\left.\mathrm{kg}^{-1}\right)$. Assim como ocorre com os PSs de algas vermelhas, os resultados indicam que os PSs de algas verdes também possuem atividades biológicas distintas in vivo.

Palavras-chave: alga verde, polímeros sulfatados, eventos biológicos, sistema de coagulação, trombose.

\section{INTRODUCTION}

In recent years, the medical potential of sulfated polysaccharides (SPs) has attracted the attention of the scientists. These anionic polymers occur at high concentrations in marine algae (RODRIGUES et al., 2009; RODRIGUES et al., 2010a). Its anticoagulant and antithrombotic actions are among the most widely studied (FARIAS et al., 2001; ROCHA

'Programa de Pós-graduação em Biotecnologia, Rede Nordeste de Biotecnologia, Fortaleza, CE, Brasil.

IIDepartamento de Bioquímica e Biologia Molecular, Universidade Federal do Ceará (UFC), Av. Mister Hull, s/n, 60451-970, Fortaleza, CE, Brasil. E-mail: nmbb@ufc.br. *Autor para correspondência.

IIIInstituto de Bioquímica Médica, Universidade Federal do Rio de Janeiro (UFRJ), Rio de Janeiro, RJ, Brasil. 
et al., 2005; FONSECA et al., 2008). However, SPs have been mainly studied from red and brown seaweeds, and fewer from green algae.

The Caulerpa species are widely distributed in tropical and subtropical areas. They have a high growth rate, and dissemination of some species due to shipping and aquaculture, for example, result in damage to the native benthonic communities. There are few studies about the biological activities of Caulerpa SPs. HAYAKAWA et al. (2000) reported that SPs from $\boldsymbol{C}$. okamurai and $\boldsymbol{C}$. brachypus are mainly composed of galactose and have the specific heparin cofactor IIdependent thrombin inhibition activity. The anticoagulant and antiviral activities of the $C$. racemosa SPs were reported by GHOSH et al. (2004). Also, studying . racemosa SPs fractions, JI et al. (2008) investigated their antitumor activities against K562 and H22 cell lines. Recently, an anticoagulant SP was isolated from the green seaweed $\boldsymbol{C}$. cupressoides by our group (RODRIGUES et al., 2010b). However, no investigation in animal model of thrombosis of green algae SPs has, to the best of our knowledge, yet been reported.

Heparin (HEP) is a member of a family of SPs called glycosaminoglycans. It is considered the most important anticoagulant drug for the prevention and treatment of venous thrombosis and pulmonary embolism, management of arterial thrombosis in patients presenting with acute myocardial infarction and in the prevention of rethrombosis after thrombolysis. Also, it is used in the prevention of thrombosis in extracorporeal circuits and hemodialysis. However, it has been widely reported for many years that HEP possesses several side effects, such as thrombocytopenia, HEP-induced thrombocytopenia, haemorrhage, and risk of contamination by viral particles (MOURÃO \& PEREIRA, 1999).

Based on these considerations, the purpose of the present study was to evaluate the in vivo antiand pro-thrombotic effects of a natural SP fraction from the green seaweed $C$. cupressoides using an experimental animal model of thrombosis. The mechanism of action suggestive of this polysaccharide was also investigated.

\section{MATERIAL AND METHODS}

\section{Experimental design}

The crude SP (cSP) was extracted from the green alga $C$. cupressoides and the anti- and prothrombotic activities of a rich fraction $\left(\mathrm{SP}_{2}\right)$ was tested in vivo. Chemical composition, APTT, and inhibitor potential of thrombin by antithrombin in the presence of $\mathrm{SP}_{2}$ were also analyzed to determine the importance of the sulfate content on APTT and its mechanism of anticoagulant action in vitro. To the in vivo assay, rats intravenously received $\mathrm{SP}_{2}$ and thromboplastin (as thrombogenic stimulus) and then the formed thrombus into the cava vena was weighted.

Marine algae and sulfated polysaccharides (SPs)

The marine green alga $\boldsymbol{C}$. cupressoides var. lycopodium (Vahl) C. Agardh (Caulerpales, Chlorophyta) was collected on seashore from the Praia do Pacheco (Caucaia, Ceará State, Brazil), and taken to the Carbohydrates and Lectins Laboratory (CarboLec), Departamento de Bioquímica e Biologia Molecular, Universidade Federal do Ceará, Brasil. The material was cleaned of epiphytes, washed with distilled water and stored at $-20^{\circ} \mathrm{C}$ until use. A voucher specimen (4977) was classified and archived by Ana Cecília Fortes Xavier at the Prisco Bezerra Herbarium, Universidade Federal do Ceará. The cSP was extracted from the green alga $\boldsymbol{C}$. cupressoides by proteolytic digestion (papain) and separated into three different fractions of SPs $\left(\mathrm{SP}_{1}\right.$, $\mathrm{SP}_{2}$ and $\mathrm{SP}_{3}$ ) by anion-exchange chromatography on a DEAE-cellulose column as described (RODRIGUES et al., 2010b).

Analysis of chemical composition and partial desulfation

The total sugars (TSs) content was estimated by phenol-sulfuric acid analysis using Dgalactose as the standard on a 96-well microplate; using an ELISA reader (Amersham Biosciences, Biotrak II) at $492 \mathrm{~nm}$. Free sulfate (FS) and contaminant proteins contents were also measured as described (RODRIGUES et al., 2010b). Desulfation of the pyridinium salt of the cSP with dimethylsulfoxide was carried out at $80^{\circ} \mathrm{C}$ for $4 \mathrm{~h}$ (NAGASAWA et al., 1977).

Activated partial thromboplastin time (APTT)

Activated partial thromboplastin time (APTT) (CLOT, Bios diagnóstica, São Paulo, Brazil) of $\mathrm{SP}_{2}$ was performed in vitro using citrated normal human plasma (eleven different donors), according to the manufacturers' specifications, for detect the presence of the anti-clotting effect (RODRIGUES et al., 2010b) before of the in vivo assay. Unfractionated heparin (UHEP) (193IU mg ${ }^{-1}$ ) (fourth International Standard (85/ 502)) from the National Institute for Biological Standards and Control (Potters Bar, UK) was used as control.

The test of inhibition of thrombin by AT in the presence of $\mathrm{SP}_{2}$ was performed using incubations in 96-well plates as described by FONSECA et al. (2008). Briefly, the final concentration of reactants included 50nMAT, 2nM factor IIa and $0-1000 \mu \mathrm{g} \mathrm{mL}^{-1} \mathrm{SP}_{2}$ in $30 \mu \mathrm{L}$ of TS/PEG buffer $(0.02 \mathrm{M}$ Tris/HCl, $0.15 \mathrm{M} \mathrm{NaCl}$, and $1.0 \mathrm{mg} \mathrm{mL}^{-1}$ polyethylene glycol 8,000, $\mathrm{pH} 7.4$ ). Factor IIa was added last to initiate the reaction. After 60 
seconds (s) of incubation at $37^{\circ} \mathrm{C}, 25 \mu \mathrm{L}$ chromogenic substrate S-2238 $(0.4 \mathrm{mM})$ for factor IIa was added, and the absorbance at $405 \mathrm{~nm}$ was recorded for $120 \mathrm{~s}$ (Plate reader Thermo-max, America Devices). The rate of change of absorbance was proportional to the thrombin activity remaining in incubations mixtures. We considered $100 \%$ of thrombin activity a control made using the reactants without the addition of the $\mathrm{SP}_{2}$ $\left(100 \mu \mathrm{L}\right.$ final volume of the reaction) and $\mathrm{IC}_{50}$ is the concentration of a given $\mathrm{SP}_{2}$ required for $50 \%$ inhibition of factor IIa.

\section{Effect on thrombosis}

Antithrombotic activity was investigated in rats with rabbit brain thromboplastin as the thrombogenic stimulus. Rats (220-250g) (both sexes, 5 animals per dose) were anesthetized with an intramuscular injection of $100 \mathrm{mg} \mathrm{kg}^{-1}$ body weight of ketamine (Cristália, São Paulo, Brazil) and $16 \mathrm{mg} \mathrm{kg}^{-1}$ body weight of xylazine (Bayer AS, São Paulo, Brazil). Each animal had the right vena cava exposited and dissected. Different doses of $\mathrm{SP}_{2}$ or heparin (fourth International Standard (85/502), National Institute for Biological Standards and Control, Potters Bar, UK) were intravenously infused and allowed to circulate for $5 \mathrm{~min}$. After that, the inferior vena cava was isolated, and brain thromboplastin $\left(5 \mathrm{mg} \mathrm{kg}^{-1}\right.$ body weight) from Biolab-Merieux AS (Rio de Janeiro, Brazil) was slowly injected intravenously; after $1 \mathrm{~min}, 0.7 \mathrm{~cm}$ of isolated vena cava was clamped off using distal and proximal sutures. The formed thrombus inside the occluded segment was pulled out after $20 \mathrm{~min}$ stasis, and then washed with $0.15 \mathrm{M}$ saline solution, dried $\left(1 \mathrm{~h}, 60^{\circ} \mathrm{C}\right)$ and weighted. Mean thrombus weight was obtained by the average weight from each group and then expressed as percentages of the weight. It was considered $100 \%$ representing complete inhibition of thrombosis formation (presence of the $\mathrm{SP}_{2}$ ). Data were expressed as mean \pm standard error of the mean (S.E.M.) (FONSECA et al., 2008). The differences among the groups were analyzed using one-way ANOVA followed by Tukey' test. $P<0.05$ was considered statistically significant.

\section{RESULTS AND DISCUSSION}

The C. cupressoides crude SP (Cc-cSP) was isolated by papain digestion $\left(6 \mathrm{~h}, 60^{\circ} \mathrm{C}\right)$, and was composed by three different SPs fractions $\left(\mathrm{SP}_{1}, \mathrm{SP}_{2}\right.$, and $\mathrm{SP}_{3}$ ), when eluted at different $\mathrm{NaCl}$ concentrations (DEAE-cellulose). The presence of SPs in the fractions was also checked by agarose gel electrophoresis (data not shown). Also, to check the presence of the anticlotting effect of $\mathrm{SP}_{2}$, the APTT test was performed.
Thus, only fraction $\mathrm{SP}_{2}$ has in vitro anticoagulant effect as described (RODRIGUES et al., 2010b). In the present study, we intended to investigate the antithrombotic activity of $\mathrm{SP}_{2}$.

It has been accepted that the Caulerpa polysaccharides are mainly composed by galactose (HAYAKAWA et al., 2000), but the chemical composition of their SPs fractions may vary (JI et al., 2008). Based on the fact that algae SPs vary according to species, extraction procedure, season of harvest, and local climatic conditions, the chemical composition of the Cc-cSP and their SPs fractions was determined. All polysaccharides contained high TSs content (data not shown). The highest free sulfate (FS) content was obtained in the Cc-cSP (22.39\%) and $\mathrm{SP}_{2}(21.12 \%)$ fraction, respectively. In addition, no CP was detected, suggesting the efficiency of extraction method used (RODRIGUES et al., 2010a; 2010b). Cc-cSP was submitted to chemical desulfation by solvolysis after $4 \mathrm{~h}$ (NAGASAWA et al., 1977). However, this procedure yet resulted in about $9.92 \%$ of sulfate, showing clearly an incomplete desulfation. Similarly, GHOSHet al. (2004) also reported an inefficient desulfation of a hot cSP from C. racemosa.

The presence of an in vitro anticoagulant activity of $\boldsymbol{C}$. cupressoides polysaccharides fractions was previously measured before of the in vivo assay. As expected, only the $\mathrm{SP}_{2}$ fraction showed anti-clotting effect and was less active than UHEP $\left(\sim 20 \mathrm{IU} \mathrm{mg}^{-1}\right)$. Based on the hypothesis that the sulfate is important for the anticoagulant and antithrombotic actions (MOURÃO \& PEREIRA, 1999; FONSECA et al., 2008; MELO \& MOURÃO, 2008), we performed an inhibition factor IIa by AT assay in the presence of the $\mathrm{SP}_{2}$ fraction. Hence, figure 1 shows that this fraction has the ability to induce inhibition of thrombin mediated by AT. The $\mathrm{IC}_{50}$ for factor IIa inhibition by AT, estimated by the curve in figure 1, was about $10.0 \mu \mathrm{g} \mathrm{mL}^{-1}$ for $\boldsymbol{C}$. cupressoides $\mathrm{SP}_{2}$, demonstrating that this molecule interfere on the coagulation cascade. The same property was also observed for $\mathrm{UHEP}\left(\mathrm{IC}_{50} \sim 0.7 \mu \mathrm{g} \mathrm{mL}^{-1}\right)$.

In this study, an incomplete desulfation was noted in the crude extract of $\boldsymbol{C}$. cupressoides SPs when compared to that of GHOSH et al. (2004). In contrast, the result obtained by the inactivation of factor IIa by AT assay reported here do not agrees with other descriptions for eight different SPs isolated from Caulerpa spp., Codium spp. and Monostroma spp. (Chlorophyta) polysaccharides in the literature (HAYAKAWA et al., 2000). In addition, the Codium polysaccharides were desulfated and did not exhibit thrombin inhibition, however no correlation was found between the content of sulfate in the molecules and the extent of thrombin inhibition. All isolated polymers 


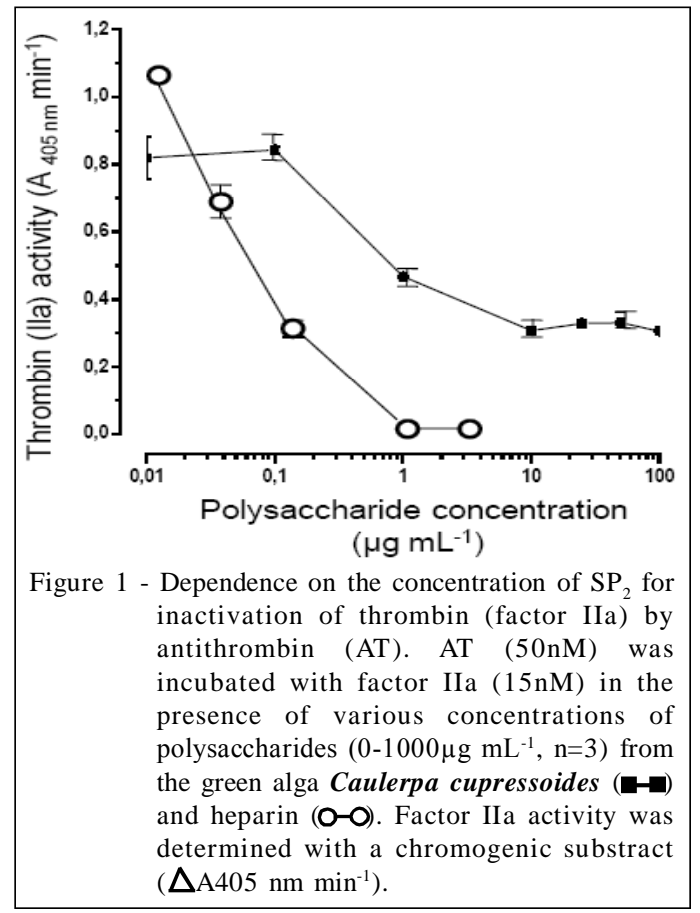

of these species had specific heparin cofactor IIdependent thrombin inhibition, but their abilities to inhibition thrombin are not as strong as that of UHEP. Therefore, SPs from Chlorophyta activate heparin cofactor II primarily by a mechanism different from displacement and template mechanisms.

Based on our findings, we suggest that $\mathrm{SP}_{2}$ isolated from $\boldsymbol{C}$. cupressoides has a specific ATdependent thrombin inhibition activity (Figure 1). MATSUBARA et al. (2001) isolated a sulfated galactan from Codium cylindricum and reported that this polysaccharide, which is capable of strongly prolong the APTT, has no AT and heparin cofactor II potential, but exerts a mechanistic activity on thrombin. More recently, PEREIRA et al. (2005) compared SPs from $\boldsymbol{B}$. occidentalis and $\boldsymbol{G}$ crinale (Rhodophyta) using specific proteases and coagulation inhibitors assays. The authors found that these polysaccharides do not differ in thrombin inhibition mediated by AT, however in the presence of heparin cofactor II, the G. crinale polysaccharide requires a significantly higher concentration to achieve the same inhibitory effect when compared to B. occidentalis polysaccharide. Thus, the proportion and/or the distribution of 2,3-disulfated a-units in galactan backbone may represent a specific requirement for anticoagulant action. Also, SPs may form a particular complex with plasmatic inhibitor and protease activity. The structural basis of this interaction is complex because it involves naturally heterogeneous polysaccharides, but depends on the distribution of sulfate groups and on the monosaccharide composition.

As a rule, the antithrombotic effects of SPs in animal experiments are required the anti-factor $\mathrm{Xa}$ activity as a prerequisite for a thrombosis-preventing effect (FARIAS et al., 2001; FONSECA et al., 2008). However, this hypothesis may be contrasting to their in vivo effects. ROCHA et al. (2005) evaluated a sulfated galactofucan from the brown alga Spatoglossum schröederi on several in vitro assays and noted that this molecule has no anticoagulant activity. The authors tested this SP using an animal model of experimental venous thrombosis and verified its ability to reduce time-dependent manner the thrombus formation in rats. Also, it was observed its property to induce 2-fold more potency than UHEP the stimulating of the synthesis of an antithrombotic SP by endothelial cells.

Although the effect of $\mathrm{SP}_{2}$ fraction in the inhibition of factor Xa by antithrombin assay has been not tested, we extended our studies to investigate this molecule using an experimental venous thrombosis model in rats. As expected, it was observed that a single injection of UHEP in a bolus, given $5 \mathrm{~min}$ before the thrombogenic stimulus, produced a dose-dependent inhibition of thrombus formation $\left(\sim 0.5 \mathrm{mg} \mathrm{kg}^{-1}\right.$ body weight, $\sim 70 \%$ of inhibition). A complete inhibition of thrombus formation was obtained at high doses of UHEP $\left(\sim 0.7-2.5 \mathrm{mg} \mathrm{kg}^{-1}\right.$ body weight, $100 \%$ of inhibition). Using the same procedure, the administration of different doses of $\mathrm{SP}_{2}$ had also inhibition of thrombosis effect. However, two different biological effects were observed (Figure 2A). Surprisingly, low doses of $\mathrm{SP}_{2}$ from the green alga $\boldsymbol{C}$. cupressoides prevents thrombus formation (1.0 and $2.0 \mathrm{mg} \mathrm{kg}^{-1}$ body weight) about $29.87 \%$ (3.24 $\pm 0.45 \mathrm{mg}$, mean \pm S.E.M. $)$ and $70.56 \%(1.36 \pm 0.37 \mathrm{mg}$, mean \pm S.E.M. $)$ $(\mathrm{P}<0.05)$, compared to the saline group $(4.62 \pm 0.66 \mathrm{mg}$, mean \pm S.E.M. $)$, whereas at higher doses $\left(>2.0 \mathrm{mg} \mathrm{kg}^{-1}\right.$ body weight) the inhibition was not observed. Similarly, a natural SP isolated from the algae $\boldsymbol{B}$. occidentalis showed the same effects using this experimental model (FARIAS et al., 2001).

More recently, FONSECA et al. (2008) evaluated two sulfated galactans extracted from $\boldsymbol{B}$. occidentalis and G. crinale. Both polysaccharides exhibited procoagulant and protrombotic effects. Although these molecules have an identical saccharide structure and the same size chain, slightly differ in their sulfation patterns. These distinct properties also confer different anticoagulant and venous antithrombotic activities. SP from $\boldsymbol{B}$. occidentalis is considered a potent heparinoid at low concentrations (inhibiting venous thrombosis), but this effect is reverted at higher concentrations. According to the authors these 

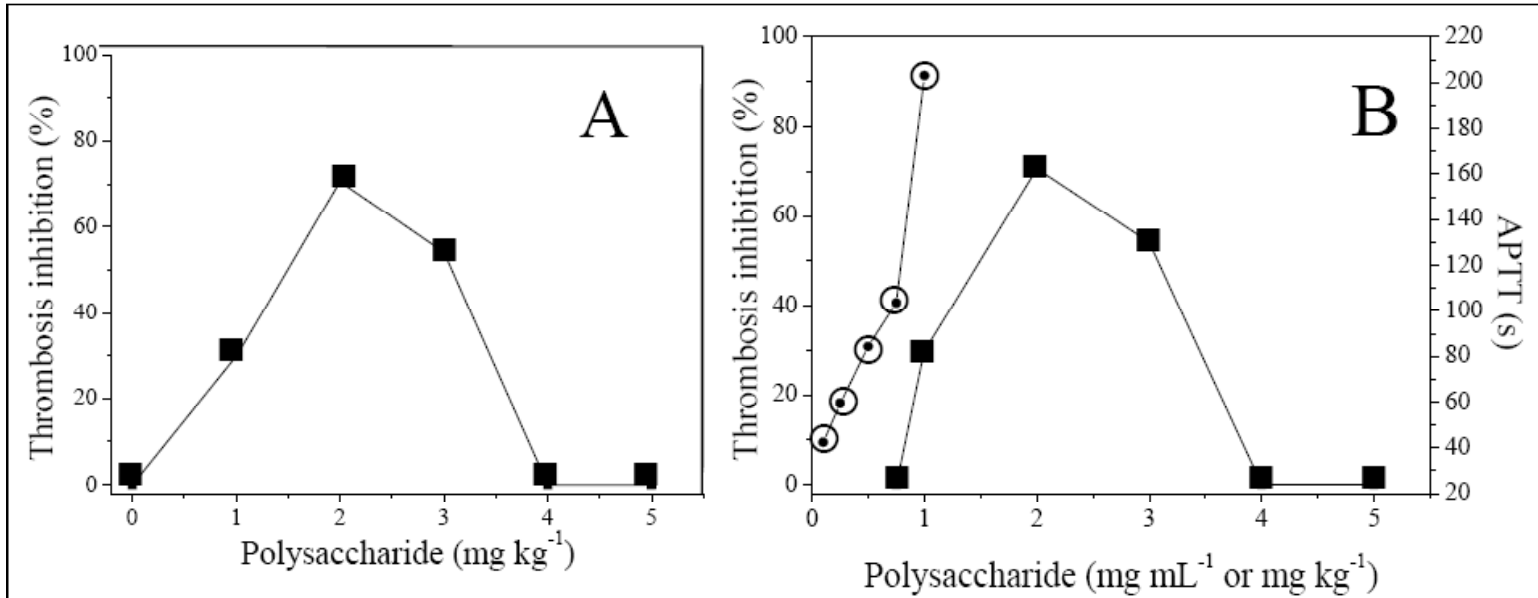

Figure 2 - Antithrombotic effect after intravascular administration of Caulerpa cupressoides SP2 in rats. Venous antithrombotic activity was investigated using a stasis thrombosis model that combines stasis and hypercoagulability. A, Different doses of $\mathrm{SP}_{2}$ were administered and allowed to circulate for $5 \mathrm{~min}$. Thromboplastin ( $5 \mathrm{mg} \mathrm{kg}^{-1}$ body weight) was slowly injected intravenously, and $0.7 \mathrm{~cm}$ of the isolated vena cava segment was tied off. The results were expressed as $\%$ of the weight (means, $\mathrm{n}=5, \mathrm{P}<0.05$ vs control), $100 \%$ representing complete inhibition of thrombosis (thrombus weight in the presence of $\mathrm{SP}_{2}$ administration). $B$, Correlation between the in vitro anticoagulant action and in vivo antithrombotic effect. (O-O) activated partial thromboplastin time test (APTT); (- $\mathbf{-})$ experimental animal model of venous thrombosis.

structural differences could be critical for the interaction between proteases, inhibitors and activators of the coagulation system.

Regarding our study, these events are reported uniquely for SPs isolated from red seaweeds (FARIAS et al., 2001; FONSECA et al., 2008), but are not described for SPs from Chlorophyta. $\mathrm{SP}_{2}$ shows a similar activity profile compared to these reports (Figure 2A). As proposed by MOURÃO \& PEREIRA (1999), we also verified that $C$. cupressoides $\mathrm{SP}_{2}$ modifies the coagulation time at low concentration in vitro $(0.1 \mathrm{mg}$ $\left.\mathrm{mL}^{-1}\right)$, but requires a 10 -fold higher $\left(1.0 \mathrm{mg} \mathrm{mL}^{-1}\right)$ concentration of $\mathrm{SP}_{2}$ to exhibit an in vivo antithrombotic action (Figure 2B). In this context, we evaluated $\mathrm{SP}_{2}$ on a haemorrhage model and observed that a dose of $2.0 \mathrm{mg} \mathrm{kg}^{-1}$ (better antithrombotic dose) could not produce haemorrhagic events in comparison to UHEP (data not shown). These data suggest further a subsequent investigation using this molecule in a platelet aggregation test to evaluate its possible action. This study may help to delineate a close relationship at different biological effects (FARIAS et al., 2001; ROCHA et al., 2005).

In order to investigate these dual effects, MELO \& MOURÃO (2008) evaluated different fragments of the sulfated galactan from $B$. occidentalis. The natural polysaccharide has the ability to enhance thrombin and factor Xa inhibition by antithrombin and/ or heparin cofactor II. It is less active in arterial thrombosis, but in a venous thrombosis presents a dual effect. This event was considered as a consequence of two actions, one on thrombin and factor Xa inhibition and another on inducing the factor XII activation. In order to separately analyse these two effects, the authors prepared sulfated galactan derivates and polysaccharide of low molecular weights were tested. The major results showed that the administration of fragments of $5 \mathrm{kDa}$ are capable of extinguishing the effect on factor XII activation and a similar effect is obtained compared to UHEP. Therefore, a similar study also suggest to $C$. cupresseoides $\mathrm{SP}_{2}$ fraction described here.

In conclusion, our studies show for the first time a natural SP isolated from green algae $(\boldsymbol{C}$. cupressoides) presenting anti- and prothrombotic actions. Our results suggest that Chlorophyta polysaccharides could also be used as biotechnological tools for studies of the coagulation system. Considering the side effects of the administration of UHEP, SPs from green algae could also represent an alternative as antithrombotic drugs.

\section{ACKNOWLEDGEMENTS}

We are grateful to Conselho Nacional de desenvolvimento Científico e Tecnológico (CNPq), Rede Nordeste de Biotecnologia (Renorbio), Coordenação de Aperfeiçoamento de pessoal de Nível Superior (Capes) and Fundação Cearence de Apoio ao Desenvolvimento Científico e Tecnológico (Funcap). BENEVIDES, N.M.B. and MOURÃO, P.A.S. are seniors investigators of $\mathrm{CNPq} / \mathrm{Brazil}$. 


\section{BIOETHICS AND BIOSSECURITY COMMITTEE APPROVAL}

This study was approved by the Comitê de Ética e Pesquisa Animal da Universidade Federal do Ceará (UFC) under number $125 / 07$.

\section{REFERENCES}

FARIAS, W.R.L. et al. Dual effects of sulfated D-galactans from the red alga Botryocladia occidentalis preventing thrombosis and inducing platelet aggregation. Thrombosis and Haemostasis, v.86, n.6, p.1540-1546, 2001.

FONSECA, R.J.C. et al. Slight differences in sulfatation of algal galactans account for differences in their anticoagulant and venous antithrombotic activities. Thrombosis and Haemostasis, v.99, n.3, p.539-545, 2008. Available from: <http://www.schattauer.de/de/magazine/uebersicht/zeitschriftena-z/thrombosis-and-haemostasis/contents/archiv/issue/348/ manuscript/9459.html>. Accessed: Jan. 28, 2011. doi: 10.1160/ TH07-10-0603.

GHOSH, P. et al. In vitro anti-herpetic activity of sulfated polysaccharide fractions from Caulerpa racemosa. Phytochemistry, v.65, n.23, p.3151-3157, 2004. Available from: <http:// www.sciencedirect.com/science?_ob=ArticleURL\&_udi=B6TH74DDXM2R1\&_user $=10 \&$ _coverDate $=12 \% 2 \mathrm{~F} 01 \% 2 \mathrm{~F} 2004$ \&_alid $=14$ $13693741 \&$ rdoc $=1 \&$ fmt=high\&_orig=search\&_cdi=5275\&_sort

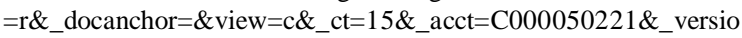
$\mathrm{n}=1 \& \_$urlVersion $=0$ \&_userid=10\&md5=347295dbda68e00f291e $51 \mathrm{c} 0 \mathrm{~d}$ 237b926>. Accessed: Jan. 28, 2011. doi: 10.1016/ j.phytochem.2004.07.025.

HAYAKAWA, Y. et al. Inhibition of thrombin by sulfated polysaccharides isolated from green algae. Biochimica et Biophysica Acta, v.1543, n.1, p.86-94, 2000. Available from: <http://www.sciencedirect.com/ science?_ob=ArticleURL\&_udi=B 6 T 21 - 41 P $179 \mathrm{~V}$ \&_user=10\&_coverDate $=11 \% 2 \mathrm{~F} 30 \% 2 \mathrm{~F} 2000 \& \_a l i d=1623211251 \& \_\mathrm{r}$ doc $=1 \& \_f m t=h i g h \& \_o r i g=s e a r c h \& \_o r i g i n=s e a r c h \& \_z o n e=r s l t$ list_item \&_cdi $=4905 \& \_s o r t=r \& \_s t=13 \& \_d o c a n c h o r=\& v i e w=c \& \_c t=10$ $3 \& \_$acct $=$C 000050221 \&_version $=1$ \&_urlVersion $=0$ \&_userid $=10$ $\& \mathrm{md} 5=648 \mathrm{~b} 0 \mathrm{~d} 41 \mathrm{e} 6 \mathrm{bf8}$ a8f4b0ee1ec9256f442\&searchtype $=\mathrm{a}>$. Accessed: Jan. 28, 2011. doi: 10.1016/S0167-4838(00)00193-X.

JI, H. et al. Separation of the polysaccharides in Caulerpa racemosa and their chemical composition and antitumor activity. Journal of Applied Polymer Science, v.110, n.3, p.14351440, 2008. Available from: <http://onlinelibrary.wiley.com/ doi/10.1002/app.28676/abstract>. Accessed: Jan. 28, 2011. doi: 10.1002/app.28676.

MATSUBARA, K. et al. Anticoagulant properties of a sulfated galactan preparation from a marine green alga, Codium cylindricum. International Journal of Biological Macromolecules, v.28, n.5, p.395-399, 2001. Available from: $<\mathrm{ht} \mathrm{t} \mathrm{p}: / / \mathrm{w}$ w w. s c i e n c e di r e c t. c o m/ science?_ob=ArticleURL\&_udi=B 6T 7J-42VV8G9$8 \& \_$user $=10 \&$ \&coverDate $=06 \% 2 \mathrm{~F} 12 \% 2 \mathrm{~F} 2001 \&$ \&alid $=1623214$ $569 \& \_r d o c=1 \& \_f m t=h i g h \& \_o r i g=$ search \&_origin $=$ search \&_zon e=rslt_list_item $\&$ ccdi $=5060 \&$ sort $=r \&$ st $=13 \&$ _docanchor $=\& \mathrm{v}$ iew $=$ c\&_ct $=19 \& \_$acct $=C 000050221 \& \_$version $=1$ \&_urlVersion $=$ 0\&_userid=10\&md5=17efa44cb588961 c012f0a53fc9f3c49\&se archtype $=\mathrm{a}>$. Accessed: Jan. 28, 2011. doi: 10.1016/S01418130(01)00137-4.

MELO, F.R.; MOURÃO, P.A.S. An algal sulfated galactan has an unusual dual effect on venous thrombosis due to activation of factor XII and inhibition of the coagulation proteases. Thrombosis and Haemostasis, v.99, n.2, p.531-538, 2008. Available from: $<\mathrm{ht} \mathrm{t}$ p: / / w w w. s c i e n c e d i r e c t . c o m / science?_ob=ArticleURL\&_udi=B6T1 W-4SM62DT1\&_user $=10 \&$ ccoverDate $=09 \% 2 \mathrm{~F} 30 \% 2 \mathrm{~F} 2008 \&$ \&alid $=16232171$ $32 \& \_r d o c=1 \& \_f m t=h i g h \&$ orig $=$ search\&_origin=search\&_zon $\mathrm{e}=\mathrm{rslt} \_$list_item\&_cdi $=4901 \&$ sort=r\&_st=13\&_docanchor $=\& \mathrm{view}=\mathrm{c}$ \&_ct=2\&_acct=C000050221\&_version=1\&_urlVersion=0\&_userid $=1$ $0 \& \mathrm{md} 5=\mathrm{ee} 53 \mathrm{bb} 51 \mathrm{~b} 0669 \mathrm{e} 1436 \mathrm{~d} 5 \mathrm{ba} 966 \mathrm{a} 80 \mathrm{eb} 1 \mathrm{~b} \&$ searchtype $=\mathrm{a}>$. Accessed: Jan. 28, 2011. doi: :10.1016/j.bbagen.2008.05.006.

MOURÃO, P.A.S.; PEREIRA, M.S. Searching for alternatives to heparin: sulfated fucans from marine invertebrates. Trends in Cardiovascular Medicine, v.9, n.8, p.225-232, 1999. Available from: <http://www.sciencedirect.com/ s c i ence ? _ o b = A r t i c le UR L \&_u di = B 6 T 1 D 41S51YR\&_user $=10 \&$ coverDate $=11 \% 2 F 30 \% 2 F 1999$ \&_alid $=1623$ $222582 \&$ rdoc $=1 \&$ \& fmt $=$ high \&_orig $=$ search\&_origin $=$ search \&_zone $=$ rslt_list_item $\&$ _cdi $=4888 \&$ \&st $=13 \&$ \&docanchor $=\&$ view $=c \&$ ct $=14 \&$ acct $=\mathrm{C} 000050221 \&$ version $=1 \&$ urlVersi on $=0 \& \_u s e r i d=10 \& m d 5=1 \mathrm{c} 347 \mathrm{dceb} 39 \mathrm{bbd} 31 \mathrm{~d} 2 \mathrm{a} 6978873 \mathrm{e} 34 \mathrm{a} 6 \mathrm{c} \& \mathrm{se}$ archtype $=\mathrm{a}>$. Accessed: Jan. 28, 2011. doi: 10.1016/S10501738(00)00032-3.

NAGASAWA, K. et al. Solvolytic desulfation of glycosaminoglycan sulfates with dimethyl sulfoxide containing water or methanol. Carbohydrate Research, v.58, p.47-55, 1977.

PEREIRA, M.G. et al. Structure and anticoagulant activity of a sulfated galactan from the red alga, Gelidium crinale. Is there a specific structural requirement for the anticoagulant action? Carbohydrate Research, v.340, n.12, p.20152023, 2005. Available from: <http://www.sciencedirect.com/ science?_ob=ArticleURL\&_udi=B 6 TFF-4 GMJ 99 J $3 \& \_u s e r=10 \& \_c o v e r D a t e=09 \% 2 \mathrm{~F} 05 \% 2 \mathrm{~F} 2005 \& \_$rdoc $=13 \& \_\mathrm{fmt}=\mathrm{hi}$ gh\&_orig=browse\&_srch=docinfo $\% 28 \% 23$ toc $\% 235225 \% 23200$ $5 \% 23996599987 \% 23602848 \% 23$ FLA\%23display\%23Volume $\%$ 29\&_cdi $=5225 \& \_s o r t=d \& \_d o c a n c h o r=\& \_c t=21 \& \_a c c t=C 0000$ 50221 \&_version $=1$ \&_urlVersion $=0 \& \_u s e r i d=10 \& \mathrm{md} 5=80 \mathrm{ec} 5 \mathrm{f} 5 \mathrm{a} 11$ 30 cbb64641f412c58816be>. Accessed: Jan. 28, 2011. doi: 10.1016/j.carres.2005.05018.

ROCHA, H.A.O. et al. Structural and hemostatic activities of a sulfated galactofucan from the brown alga Spatoglossum schröederi. An ideal antithrombotic agent? Journal of Biological Chemistry, v.280, n.50, p.41278-41288, 2005. Available from: <http://www.jbc.org/content/280/50/41278.full.pdf+html>. Accessed: Jan. 28, 2011. doi: 10.1074/jbc.M501124200.

RODRIGUES, J.A.G. et al. Extração e atividade anticoagulante dos polissacarídeos sulfatados da alga marinha vermelha Halymenia pseudofloresia. Revista Ciência Agronômica, v.40, n.2, p.224-231, 2009. Available from: <http:// www.ccarevista.ufc.br/seer/index.php/ccarevista/article/view/ 515/333>. Accessed: Jan. 28, 2011.

RODRIGUES, J.A.G. et al. Isolamento, fracionamento e atividade anticoagulante de iota-carragenanas da Solieria filiformis. Ciência Rural, v.40, n.11, p.2310-2316, 2010a. Available from: <http:/ $/$ www.scielo.br/scielo.php? script=sci_abstract \&pid=S0103$84782010001100010 \& \operatorname{lng}=$ pt\&nrm $=$ iso $\&$ tlng $=p t>$. Accessed: Jan. 28, 2011. doi: 10.1590/S0103-84782010001100010.

RODRIGUES, J.A.G. et al. Polissacarídeos sulfatados isolados das clorofíceas Caulerpa racemosa e Caulerpa cupressoides extração, fracionamento e atividade anticoagulante. Acta Scientiarum. Biological Sciences, v.32, n.2, p.113-120, 2010b. Available from: <http://periodicos.uem.br/ojs/index.php/ ActaSciBiolSci/article/view/5923/5923>. Accessed: Jan. 28, 2011. doi: 10.4025/actascibiolsci.v32i2.5923.

Ciência Rural, v.41, n.4, abr, 2011. 